\title{
Designing Collaborative Learning Environments Using Educational Scenarios Based on Self-regulation
}

\author{
doi:10.3991/ijac.v2i1.606 \\ F. Paraskeva, S. Mysirlaki and E. Choustoulakis \\ University of Piraeus, Piraeus, Greece
}

\begin{abstract}
As more and more studies acknowledge that students are basic contributors to the learning process, factors such as self concept, (computer) self-efficacy and self-regulation are important in enhancing human performance. Nevertheless, these learner characteristics have received little attention in the e-learning environment. This paper presents the results of a study indicating significant positive relationships between learner characteristics, such as self-concept (academic achievement and job achievement), Computer Self Efficacy (CSE) and Self-Regulation (SR) constructs. Acknowledging the requirement for a strong shift of students towards developing self-regulated scenarios and strategies, we suggest that collaborative e-learning environments should be designed according to the self-regulated theory and selfbeliefs. As a result, in this study we present a model examining how we can design educational scenarios based on self-regulation theory in a collaborative e-learning environment. This model is a tool for conducting experiments in e-learning university courses, studying the design, development and evaluation of the collaborative learning process.
\end{abstract}

Index Terms-Collaborative Learning Environments, SelfConcept, (Computer) Self-Efficacy, Self-Regulation.

\section{INTRODUCTION}

Today's information and knowledge based society requires individuals with knowledge, skills and (selfvalues), able to manage the diffusion of the enormous volume of information and knowledge. Educational, training or other expertise programs could support these requirements to the individuals as learners.

In this direction, scientific researchers have noted that the goals of the educational, training and academic programs (including e-learning programs) should foster/enhance individuals to become capable, independent, self-regulated and efficient learners [1, 2].

Accordingly, tertiary education has to emphasize this dimension, fostering personality characteristics of the learners that could enhance self-development such as motivation, self-believes, self-efficacy, learning strategies, management resources and information. Developing these personality characteristics, the learners are going to be flexible, independent, confident and effective in managing their own learning activities [3, 4]. These internal characteristics could influence the self-regulated strategies in the learning environment through the development of goal setting, cognitive \& meta-cognitive strategies, critical thinking, resource management etc.

According to the aforementioned hints, the use of technology in tertiary learning environments, such as elearning programs (digital tools, software, as well as shared virtual practices), are still not incorporating the educational or psychological dimensions in an authentic learning context $[5,6]$.

Therefore, the new learning environments could create collaborative tools and practices, or educational scenarios, to promote efficient procedures of learning and selfregulated strategies that would enable learners to manage their own learning via peer learning, active roles, and authentic methods of learning and assessments [6, 7]. These tools and procedures have to include motivations, goal-setting and planning, seeking, organizing and transforming information, monitoring, rehearsing and memorizing, reviewing strategies etc. [8,9].

It is claimed that although research has established the effectiveness of e-learning, the specific learner characteristics leading to performance in e-learning environments are unclear [10]. In Reference [10] it is also noted that though e-learning is becoming a trend in organizational education, research on adult work populations is limited. Moreover, there seems to be a lack of research regarding Self-Regulation and corporate elearning environments $[11,12]$. The high dropout rate of e-learning is linked with low rates of self-motivation and self-direction in e-Learning [13].

This paper is an attempt to investigate the relations between different aspects of learner characteristics, such as self-concept, Computer Self Efficacy (CSE) and SelfRegulation (SR), in order to propose a model for an elearning environment based on collaborative Selfregulated learning scenarios.

\section{THEORETICAL BACKGROUND}

Academic self-concept and academic self-efficacy have been acknowledged as unique factors that contribute to academic achievement or performance [8].

More specifically, academic self-concept refers to the individuals' knowledge and perceptions about themselves in achievement situations [14]. Academic self-concept incorporates attitudes, feelings and perceptions relative to one's intellectual or academic skills, and represents a mixture of self-beliefs and self-feelings regarding general academic performance [15]. 
Bandura defined self-efficacy as a person's "judgments of (his or her) capabilities to organize and execute courses of action required to attain designated types of performances" [16]. Numerous studies have reported how positive self-concept or self-efficacy facilitated students' academic engagement, goal-setting, task choice, persistence and effort, motivation, strategy use, performance and achievement, and even career selection etc.

Computer self-efficacy refers to the judgment of one's capability to use a computer [17]. Individuals evaluate the contributions of these sources of information, regarding their capabilities, and perform their behavior of interest. Individuals who perceive themselves capable of performing certain tasks or activities are defined as high in self-efficacy and are more likely to attempt and execute these tasks and activities. People who perceive themselves as less capable are less likely to attempt and execute these tasks and activities, and are defined as lower in selfefficacy [18].

A seminal study found that undergraduate students who possessed a low sense of self-efficacy in computer use, displayed little interest in acquiring information technologies competencies. Individuals increasing their interest in information technology, can acquire skills, expand the range of career choices and use the computer as a problem-solving tool [19].

Similar studies point out that lack of self-efficacy with regard to knowledge of information technology could prevent academic and professional development, pointing out that the self- efficacy in computer use and competence constitutes a prognostic indicator of future activities and occupational interests in information technologies [19].

People's beliefs about their self-efficacy influence academic motivation, ambitions, interest in intellectual skills, and their effort for academic performance and achievement $[18,19]$. A strong sense of efficacy creates interests in self-regulated learning environments and it could develop conditions for lifelong leaning programs. A strong sense of efficacy in basic education learners may lead students to develop competence and skills for further social and economic stability [18].

The Computer Self-Efficacy (CSE) construct has been used by researchers in order to examine the decision of individual to use information technology, software training and performance and the relationship between experience and academic performance [18, 20]. Researchers have examined the connection between CSE and several other behaviors of interest to educators. For example, research has found evidence of a positive relationship between CSE and registration in college-level computer courses, decisions to use computers and performance in software training etc $[21,22]$.

The relationship of computer experience to CSE has also been investigated by Karsten and Roth [20]. Individuals with prior computer experience are more likely to evidence higher levels of CSE than individuals without such experience. This research also showed that students' perceptions of their competence of computer use increased progressively as a result of their training. The measurement of the CSE influences the factors that are related to the training, which is of practical interest to the instructors. Results showed that the measurement of self- efficacy in computer use constitutes a practical vehicle for the evaluation of educational process [20].

Many researchers report that certain factors, such as students' beliefs, confidence and integration of instructional strategies, may lead to solid learning enhancing self-regulated and computer self-efficacy skills through technology [23, 24].

Self-regulated learning is an active process, whereby learners set goals for their learning and then attempt to monitor, regulate, and control their behaviour (motivations, self-beliefs, cognitive and meta-cognitive strategies, self-management) in order to guide their goals to their performance in the environment [25].

Most theories of self-regulation emphasize selfdevelopment, motivations, goals and achievements. Motivation helps people focus on the task, select and apply appropriate strategies, and monitor goal progress. Goals enhance self-regulation through their effects on motivation, learning strategies, self-efficacy, recourses management and self-evaluation of progress $[18,26]$.

But what happens when learning takes place in an elearning environment rather than a traditional classroom? Researchers claim that in order for computer-based learning environments to be effective, learners must be self-regulated [27]. It seems that in computer mediated environments learners must have Self-Regulation skills to level the absence of motivating and supporting factors such as group pressure, familiar learning situation, and social factors [28]. Therefore, e-learning environments should provide Self-Regulation strategies in order to maximize learners' engagement to an e-learning course.

In addition, the latest shift of educational technology to collaborative e-learning environments calls for a redesign of Self-Regulated instruction. Collaborative learning seems to support self-regulation "because peers model and discuss their own learning and motivation strategies, which are then "distributed" across the group for individuals to pick up and modify to suit their own needs" [4].

We believe that in order for students to be truly "self regulated", e-learning environments should include collaboration tools "to activate SRL efforts, mediating rather than short-circuiting or supplanting students' own learning" [29].

Yet, little research has been conducted in order to determine how a learner can develop self-regulated strategies, based on collaborative learning environments and educational theories that can encourage (adult) learners to acquire and manage knowledge and develop relevant skills and competences (knowledge, skills and values) for their academic and job performance.

Effective use of collaborative tools (such as synergo) requires ongoing user learning for students to keep up with the changing nature of the technology and the new roles in the students personal and career development (post-graduated studies, on the job training).

Different features describe different models of SRL and propose different constructs and different conceptualizations [30], but all of these models share some general assumptions and features.

Starting from the consideration 'what do we know about the impact of specific learner characteristics that 
contribute to human learning and performance in an elearning environment', the specific goal in this paper is:

- to examine the correlations of learner characteristics such as SC SE, CSE and SRL in e-learning environment.

- to propose a model for SRL to the learners in order to develop meta-cognitive and reflective skills in academic, training and career development.

Recent research suggests that there is a correlation between training and specific learner characteristics and factors of the personality. However, few of them have focused on explaining the way in which these psychological factors influence the relations of one's performance in a specific domain. Other studies have indicated that training does not have a direct influence on these factors, but it depends on the type of training and the individual's self beliefs on a specific domain. Therefore, it is clear that there is a need to explain more individual variables as potential indexes in the job and career development, since it is evident that one's self-beliefs may affect the cognitive, motivational and emotional processes. Additionally, in the context of e-learning, beliefs and training can be utilised as useful strategies to deal with the digital systems and rapid changes [31].

In this paper we describe a proposal framework developing an educational scenario for academic SRL and we propose this framework for further implementation and evaluation through the synergo (as a collaborative learning environment), developing the components of academic self-regulated learning and performance.

\section{METHOD}

The purpose of this paper is to present a framework developing an educational scenario for academic selfregulated learning for the ongoing research to develop and evaluate quantity and quality measures of different components of academic self-regulated learning by the collaborative tools (synergo, e-class).

For the purposes of our research we develop educational scenarios based in SRL and the collaborative learning environment of synergo, and e-class (open source learning management system).

\section{A. The Participants}

A total of 29 postgraduate students were recruited for participation in our research. Students were randomly assigned to participate in a research experiment, from the post-graduate program of e-learning in a Department of Digital Systems of University of Piraeus. The sample of the research was a multi-professional group of students, which included teachers, software engineers and economists. Postgraduate students were chosen because they are more likely to have developed self-regulated strategies for academic and training purposes. Moreover, the specific sample was chosen because of the requirements of the e-learning program that should

a) include appropriate learner characteristics and design personalized support that will help learners manage their online experience.

b) cover key points, including self-regulated strategies, to improve the e-learning curriculum for further meta-cognitive and reflective development in their work and career environment. c) support higher degree and standards of training program in self-regulated learning, so that learners can reflect these standards in their career and work environment (software, shared virtual learning environments, collaborative environments).

\section{B. The Instruments}

The participating students were administered a demographic questionnaire, the CSE questionnaire, and the Motivated Strategies for Learning Questionnaire (MSLQ) and Self-Perception Profile. The demographic part asked the participants to indicate their gender, age, prior knowledge, and studies, while the second questionnaire measured the self-concept, the computer self-efficacy constructs, and the self-regulated strategies developed by learners. The validity and internal consistency of the instruments used in this research have been repeatedly established by previous related research. Cronbach's Alpha Reliability coefficients for the constructs developed in our model were found to be above .70

The following instruments were completed by the participants:

Motivated Strategies for Learning Questionnaire: this questionnaire has also been employed in other studies of researching the motives, cognitive and meta-cognitive strategies and it is widely known as MSLQ. It is divided into two sub-categories. The first one explores the motivation of students and it is made up of 31 items. We used the second part which examines learning strategies and is made up of 50 items. Each item is assessed in a 7point scale from "not at all true of me" (1) to "very true of me" (7) [32].

Computer Self-Efficacy Survey: It is divided into three sub-categories. Each of them explores the beginning skills in Computer Use, the advanced skills in Computer Use and the management skills in the Use of files and other software. It is made up of 37 items. Each item is assessed on a 5-point scale from being "completely unconfident" (1) to "completely confident" (5) [33].

The demographic questionnaire in the research included information about the students' gender, age, prior knowledge, and studies.

Self-Perception Profile for College Students, by Neemann and Harter [34]. From his scale only two subscales were used tapping academic self-perception, job competence.

\section{The Procedure}

Data were collected over the course. The survey was administered to postgraduate students in a section of a course in educational psychology. Correlation analysis was used to evaluate the overall relationship between the above mentioned constructs. Assumptions of normality of distribution, linearity between variables, and absence of outliers were examined before the use of parametric statistical tests for our research needs. Results were analyzed using SPSS for Windows, Release 11.

\section{The Statistical Results OF THE Research}

The statistical results of the research are presented in Tables I and II. The appeared variables are: Self-Concept (SC, with numbers 1 and 2), Computer Self Efficacy 
(SCE, with numbers 3, 4 and 5) and Self-Regulated Learning (SLR, with numbers 6, 7, 8, 9, and 10).

TABLE I.

DesCriPTIVE STATISTICS BETWEEN SC (1 - 2), CSE (3- 5), SRL (6- 10)

\begin{tabular}{|c|c|c|c|}
\hline & $\mathbf{M}$ & SD & $\mathbf{N}$ \\
\hline 1. Academic Achievement & 50,93 & 6,866 & 29 \\
\hline 2. Job Achievement & 19,38 & 2,382 & 29 \\
\hline 3. Basic computer skills & 51,00 & 5,632 & 29 \\
\hline 4. Advanced computer skills & 60,66 & 7,513 & 29 \\
\hline 5. Files \& Software Skills & 31,55 & 3,699 & 29 \\
\hline 6. Values construct & 69,31 & 7,682 & 29 \\
\hline 7. Expectances construct & 55,28 & 6,279 & 29 \\
\hline 8. Emotions construct & 18,69 & 5,745 & 29 \\
\hline $\begin{array}{l}\text { 9. Cognitive \& metacognitive strg } \\
\text { construct }\end{array}$ & 137,14 & 14,004 & 29 \\
\hline $\begin{array}{l}\text { 10. Resource management strg } \\
\text { construct }\end{array}$ & 24,90 & 6,061 & 29 \\
\hline
\end{tabular}

Descriptive statistics for all measures are reported in Table I. Inferential statistics, such as inter-correlations among variables were used to explore the network of relationships between our research constructs. Inspection of bivariate correlations supported the assumption that positive relationships between our research variables existed.

The inspection of the Pearson $r$ correlation coefficients, reported in Table II, indicated the following positive linear relationships: Academic achievement significantly correlated with basic computer skills $(\mathrm{r}=0.418, \mathrm{p}<0.05)$, with advanced computer skills $(\mathrm{r}=0.430, \mathrm{p}<0.05)$, and also with files and software skills $(r=0.430, p<0.05)$. This highlighted the positive relationship between computerself-efficacy and academic achievement.

Also, a significant correlation was found between job achievement and basic computer skills $(\mathrm{r}=0.610, \mathrm{p}<0.01)$, advanced computer skills $(\mathrm{r}=0.538, \mathrm{p}<0.01)$, and also files and software skills $(\mathrm{r}=0.596, \mathrm{p}<0.01)$. This underlines the strong connection between education and workplace, and stresses the need for a solid technology-oriented education program in business workplaces, aiming at improving performance and computer efficacy of learners-workers. Moreover, our research confirmed the significant positive relationship between cognitive and metacognitive strategies and resource management strategies $(\mathrm{r}=0.538$, $\mathrm{p}<0.01)$.

Confirming our predictions, significant positive associations emerged between all computer self-efficacy constructs and expectances construct.

Based on a non-parametrical Mann-Whitney Test, no statistically significant difference in the use of selfregulated strategies between men and women was found $(\mathrm{z}=-.701, \mathrm{p}>0.05)$.
TABLE II.

CORRElations MatriX BETWEEN SC (1 - 2), CSE (3- 5), SRL (6- 10)

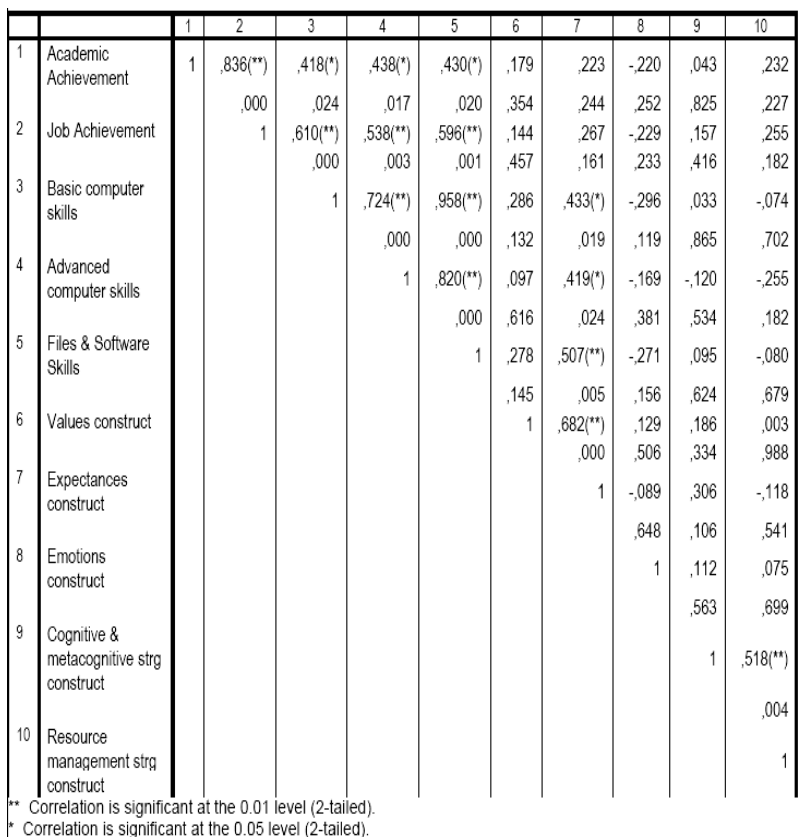

\section{The Proposed Model for Developing SElF- REgulation SCENARIOS}

The results of the research indicated significant positive relationships between specific aspects of learner characteristics, such as self-concept, academic achievement and job achievement, Computer Self Efficacy (CSE) and Self-Regulation (SR). Acknowledging this strong shift of students towards developing selfregulated skills, we propose a model for an e-learning environment based on collaborative Self-regulated learning scenarios.

The proposed model for developing and using selfregulation scenarios, based on the Learning Activity Reference Model [35], involves three steps (Fig. 1), Initializing the didactic problem, Structuring the SelfRegulation Scenario, defining the basic elements of Activity Type, Activity Technique, People, Interaction Type, Tools, and Resources, and finally, Assessing the scenario.

\section{A. Initializing the didactic problem}

In order to design a self-regulation scenario, several factors need to be specified. These introductory elements of a scenario are:

- Description of the didactic problem. At this point we specify the didactic problem which the scenario intends to solve.

- Educational Goals. This element describes the educational goal of the scenario, stemming from the didactic problem.

- Students' characteristics and needs that cover variables such as class size, grade, students' gender and social differences within the class.

- Implementation Setting. It describes the place where the scenario will be implemented (in a classroom, a virtual environment, an outdoor session). 


\section{Designing Collaborative LEARNING ENVIRONMENTS USING EDUCATIONAL SCENARIOS BASED ON SELF-REGULATION}

- Implementation Period, which stands for the implementation duration of the scenario (minutes, hours, days, months).

- Factors that influence the implementation of the scenario. This variable covers the basic factors that are needed to implement the scenario (time, basic skills, and basic technical support).

\section{B. Structuring the Self-Regulation Scenario}

After defining the initial factors, a scenario needs to be described by some elements that are used to design the learning process, based on the Learning Activity Reference Model [35]. This is the main core of the scenario, and each activity is defined by these factors:

- Activity Type. This factor describes the type of an activity, such as discussion or presentation.

- Activity Technique, which stands for the technique used to implement an activity, such as negotiation in a discussion type activity.

- People. The element of "people" represents the roles involved in an activity, such as student, teacher etc.

- Interaction Type. This factor describes the type of interaction that is involved in an activity, which could be group based, online of offline etc.

- Tools, representing the tools used during the scenario.

- Resources, which represent the source of information that is involved in an activity.

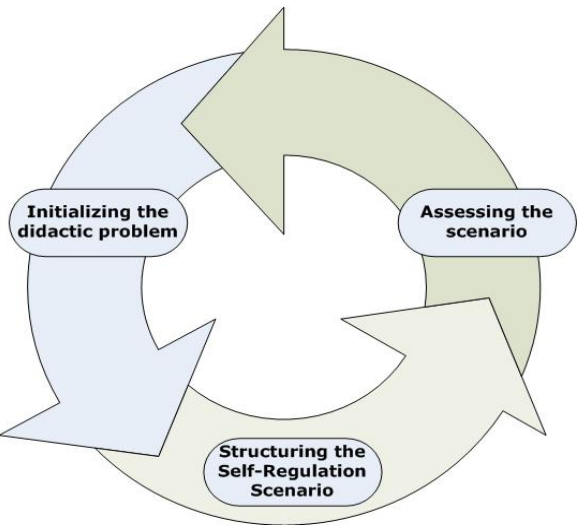

Figure 1. The proposed model

\section{Assessing the Scenario}

The last phase in designing a self-regulation scenario would be to assess it, taking into account the main didactic problem that a scenario initially aimed at solving. At this step, we should evaluate the whole scenario and its goals in order to revise them and pose new tasks equivalent to the new goals, new activities and people involved in them, new tools and resources.

\section{A TEMPLATE FOR SELF-REgULATION SCENARIOS}

Based on the main features of the Self-Regulation theory [36, 37], we propose a framework which can be used as a template for developing self-regulation teaching scenarios. The self-regulated learning strategies that will be used, in each of the self-regulation phases, are described in Table III.
TABLE III.

SElf REgulation PHASES AND LEARNING StRATEgIES

\begin{tabular}{|c|c|}
\hline Self Regulation Phase & Self-Regulated Learning Strategies \\
\hline Forethought Phase & $\begin{array}{l}\text { - Intrinsic interest } \\
\text { - Goal Setting } \\
\text { - Modelling } \\
\text { - Keeping records and monitoring } \\
\text { - Planning } \\
\text { - Task analysis } \\
\text { - Strategic planning } \\
\text { - Rehearsing and memorizing } \\
\text { - Self motivation } \\
\text { - Discuss outcome expectations } \\
\text { - Self-efficacy beliefs }\end{array}$ \\
\hline Performance Phase & $\begin{array}{l}\text { - Rehearsing and memorizing } \\
\text { - Self-control } \\
\text { - Keeping records and monitoring } \\
\text { - Self-instruction } \\
\text { - Self - observation } \\
\text { - Self-recording } \\
\text { - Seeking social assistance }\end{array}$ \\
\hline Self-reflection Phase & $\begin{array}{l}\text { - Self-Evaluation } \\
\text { - Self-monitoring } \\
\text { - Self-Judgment } \\
\text { - Self-Reaction } \\
\text { - Strategic planning } \\
\text { - Reflective Thinking } \\
\end{array}$ \\
\hline
\end{tabular}

Furthermore, a series of tools and resources could be used to implement the activities linked with the SelfRegulation Strategies. The following table presents some of these tools.

\begin{tabular}{|c|c|c|c|c|c|c|}
\hline & \multicolumn{2}{|c|}{ Forethought Phase } & \multicolumn{2}{|c|}{ Performance Phase } & \multicolumn{2}{|c|}{ Self-reflection Phase } \\
\hline $\begin{array}{c}\text { Learning } \\
\text { Procedures }\end{array}$ & $\begin{array}{r}\text { Moc } \\
\text { Discuss } \\
\text { expec } \\
\text { Reflectiv } \\
\text { Goal } \\
\text { Task } \\
\text { Strategic } \\
\text { Intrinsic in } \\
\text { moti } \\
\text { Self-effic }\end{array}$ & $\begin{array}{l}\text { lling } \\
\text { outcome } \\
\text { ations } \\
\text { Thinking } \\
\text { etting } \\
\text { alysis } \\
\text { planning } \\
\text { erest - Self } \\
\text { ation } \\
\text { cy beliefs }\end{array}$ & $\begin{array}{r}\text { Probl } \\
\text { Sel: } \\
\text { Self-C } \\
\text { Self- } \\
\text { Coll }\end{array}$ & $\begin{array}{l}\text { m Solving } \\
\text { Control } \\
\text { bservation } \\
\text { Recording } \\
\text { boration }\end{array}$ & $\begin{array}{r}\text { Self-J } \\
\text { Self -F } \\
\text { Problen } \\
\text { Reflectiv } \\
\text { Self-E }\end{array}$ & $\begin{array}{l}\text { gment } \\
\text { action } \\
\text { Solving } \\
\text { Thinking } \\
\text { uation }\end{array}$ \\
\hline Activities & $\begin{array}{r}\text { Ask for } \\
\text { impre } \\
\text { Present th } \\
\text { Model th } \\
\text { Discuss } \\
\text { Discuss the } \\
\text { impre } \\
\text { Support the } \\
\text { Enhances }\end{array}$ & $\begin{array}{l}\text { the first } \\
\text { sions } \\
\text { eproblem } \\
\text { solution } \\
\text { he model } \\
\text { new revised } \\
\text { sions } \\
\text { goal setting } \\
\text { lf-efficacy }\end{array}$ & \begin{tabular}{|r} 
Students se \\
problem \\
av \\
Students \\
observe a \\
thought \\
Student \\
Students \\
Ptudents ex \\
St
\end{tabular} & $\begin{array}{l}\text { erally solve the } \\
\text { the model is } \\
\text { ilable) } \\
\text { re advised to } \\
\text { d record their } \\
\text { and actions } \\
\text { form groups } \\
\text { eate their own } \\
\text { oblem } \\
\text { hange problems }\end{array}$ & $\begin{array}{r}\text { Students colla } \\
\text { the problems } \\
\text { clas } \\
\text { Students compa } \\
\text { according to } \\
\text { Students trace } \\
\text { the reasons th } \\
\text { Students trace } \\
\text { that lead to } \\
\text { Students ref } \\
\text { pros }\end{array}$ & $\begin{array}{l}\text { rate and solve } \\
\text { ated by their } \\
\text { ates } \\
\text { their solutions } \\
\text { me standards } \\
\text { ir mistakes and } \\
\text { lead to them } \\
\text { strategic steps } \\
\text { ue solution } \\
\text { t the whole } \\
\text { lure }\end{array}$ \\
\hline Tools & $\begin{array}{c}\text { Modeling } \\
\text { Video } \\
\text { Simulation } \\
\text { Flash }\end{array}$ & $\begin{array}{c}\text { Discussion } \\
\text { Synergo } \\
\text { Online } \\
\text { Chat } \\
\text { Message } \\
\text { Boards } \\
\text { (Forum) }\end{array}$ & $\begin{array}{c}\text { Self- } \\
\text { Recording } \\
\text { Concept } \\
\text { Map Tools } \\
\text { Camptasia }\end{array}$ & $\begin{array}{l}\text { Collaboration } \\
\text { Synergo } \\
\text { Online Chat } \\
\text { Email } \\
\text { Concept Map } \\
\text { Tools } \\
\text { Message } \\
\text { Boards } \\
\text { (Forum) } \\
\text { Video } \\
\text { conferencing }\end{array}$ & $\begin{array}{l}\text { Collaboration } \\
\text { Synergo } \\
\text { Online Chat } \\
\text { Email } \\
\text { Concept Map } \\
\text { Tools } \\
\text { Message } \\
\text { Boards } \\
\text { (Forum) } \\
\text { Video } \\
\text { conferencing }\end{array}$ & $\begin{array}{c}\text { Assessment } \\
\text { Online Tests } \\
\text { Answer } \\
\text { Sheets } \\
\text { Rubrics }\end{array}$ \\
\hline
\end{tabular}

Figure 2. Proposed tools and activities linked with the Self-Regulation Strategies

Some of the basic Tools, included in the above table, are Videos, Simulation, Concept Map Tools, Synergo, Message Boards (Forum), Online Tests, and Answer Sheets. Based on these phases and strategies we propose a framework for self-regulation scenarios presented in Fig.3. 


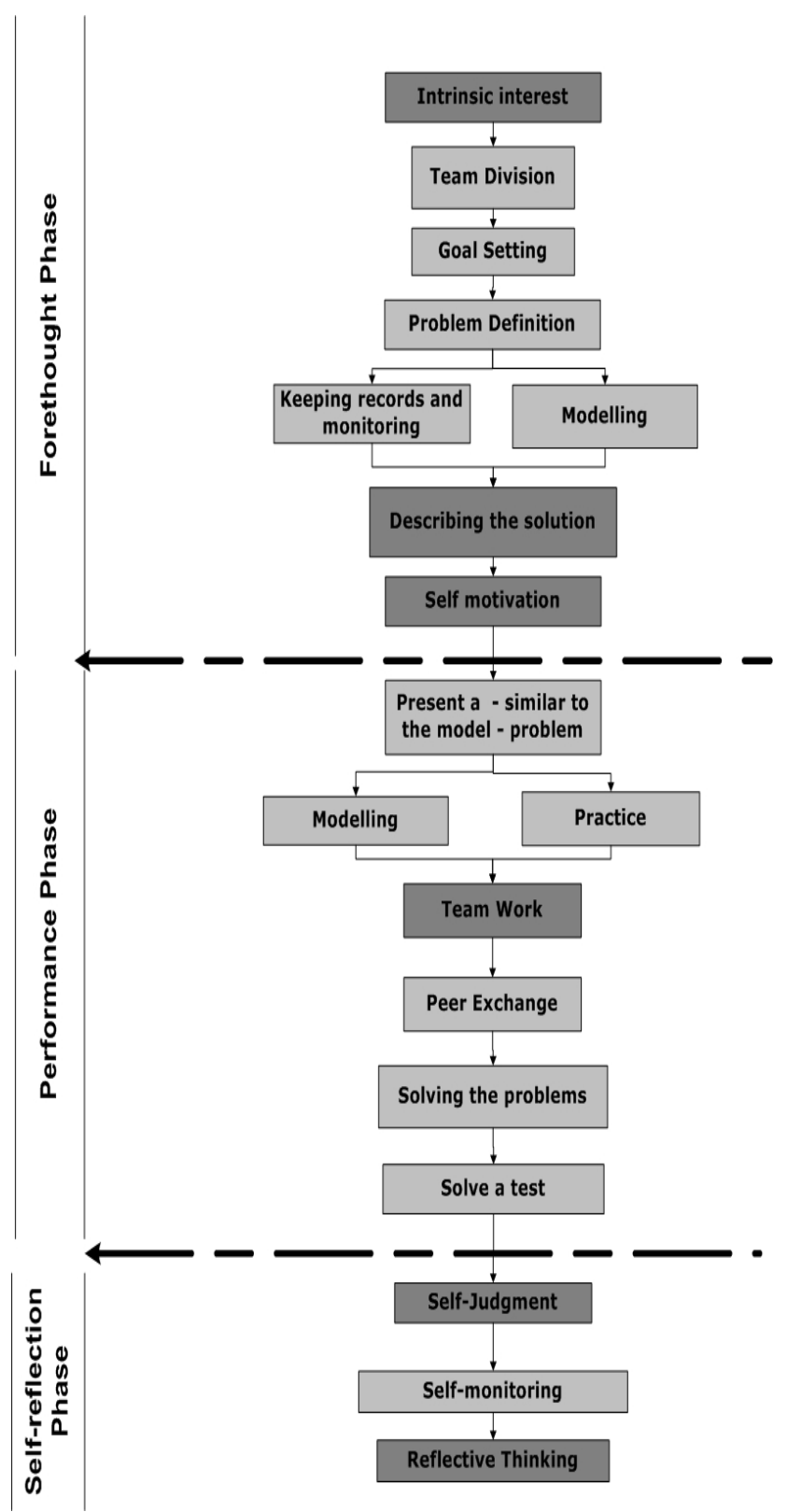

Figure 3. Self-Regulation Scenarios Template

Some of the complex activities, which are presented in the dark grey boxes in the previous figure, are analyzed in the Fig. 4.

This template is the result of an attempt to model some of the basic strategies of Self-regulation theory, in order to have a framework for developing teaching scenarios. This template can be used for developing and assessing scenarios based on Self-Regulated Learning.

\section{AN EXAMPLE OF A SELF-REGULATION SCENARIO}

The template in Fig. 4 was used to implement a selfregulated scenario as an example of a project based activity framework. This scenario was created to train post-graduated students (the sample of the pre-mentioned research) in order for them to use self-regulation strategies in their own professional field.
Intrinsic interest

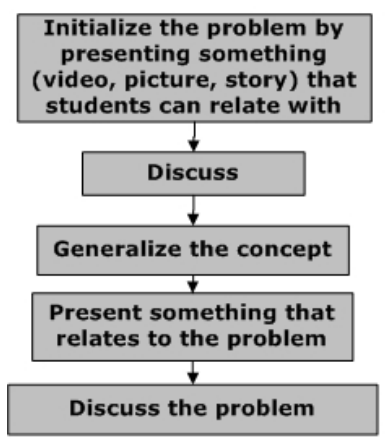

Self motivation

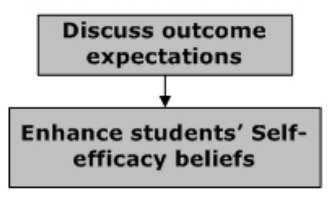

Self-Judgment

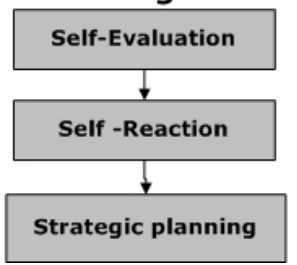

Describing the solution

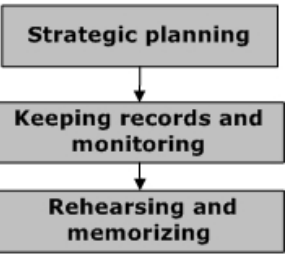

Team Work

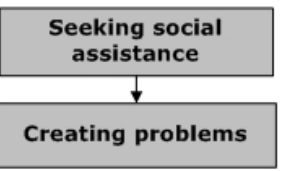

Reflective Thinking

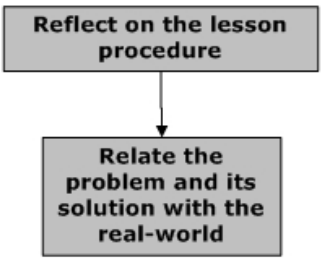

Figure 4. Analysis of the complex activities

Because of the multi-professional group of students (teachers, software engineers, economists), we created a scenario for primary education, which everyone could relate to, despite their background knowledge. As described in the proposed model for designing selfregulated scenarios, we first initialized the didactic problem (Table IV).

Second, and according to second phase of the proposed model (see Fig. 1), we decided upon the basic elements of the scenario, including Activity Type and Technique, People, Interaction Type, Tools and Resources. Some of the basic Tools which were used for the implementation of the scenario were Videos, Simulation, the Application of Synergo, Message Boards (Forum), Online Tests, and Answer Sheets.

Video and simulation applications can be used to create intrinsic interest, since these interactive characteristics seem to engage students' attention. Moreover, by visualizing the strategic steps that lead to a solution, we can model the procedure and help the students memorize it.

The Synergo environment, shown in Fig. 5, can be used to support collaborative problem solving and collaborative activity analysis and research [38]. Nowadays, design and development of computer-supported collaborative learning systems is a complicated technological endeavour, as it involves tackling difficult distributed software design issues and adaptation to the continuously shifting technological background [39]. 


\section{DESIGNING COLLABORATIVE LEARNING ENVIRONMENTS USING EDUCATIONAL SCENARIOS BASED ON SELF-REGULATION}

TABLE IV.

INITIALIZING THE DIDACTIC PROBLEM

$\begin{array}{cc}\begin{array}{c}\text { Initial Factors } \\ \text { Description of the didactic } \\ \text { problem }\end{array} & \begin{array}{c}\text { Description } \\ \text { The comprehension process } \\ \text { of transformation of verbal } \\ \text { data of problem in a } \\ \text { mathematic equation with } \\ \text { one variable } \\ \text { To identify the data of a } \\ \text { mathematical problem and } \\ \text { transform them into an }\end{array} \\ \begin{array}{c}\text { To equation } \\ \text { pose their }\end{array} \\ \begin{array}{c}\text { Students' characteristics and } \\ \text { needs }\end{array} & \begin{array}{c}\text { Students should know the } \\ \text { basic numerical operations, } \\ \text { and have basic internet skills. }\end{array} \\ \begin{array}{c}\text { Computer Lab } \\ \text { Implementation Setting }\end{array} & 3 \text { hours } \\ \text { Factors that influence the } & \text { The guarantee of required } \\ \text { implementation of the } & \text { time of work } \\ \text { scenario } & \end{array}$

Synergo supports synchronous collaboration in building diagrammatic representations (flowcharts, entityrelationship diagrams, concept maps, and data flow diagrams). The pedagogical value of Synergo framework is based on the fact that it allows the initiation of collaborative sessions with diverse settings, regarding the group size, floor control, and level of peer awareness, thus facilitating teachers to design a variety of collaborative learning activities. Various evaluation studies have been performed using applications built according to Synergo framework, and the obtained results have underlined the usefulness and functionality of such an environment.

Synergo can be used as a collaboration tool (Synergo Collaborative Mapping Environment), because it seems to foster discussion and collaboration among the students, allowing interactions that can be captured and analyzed by the use of $\log$ files.

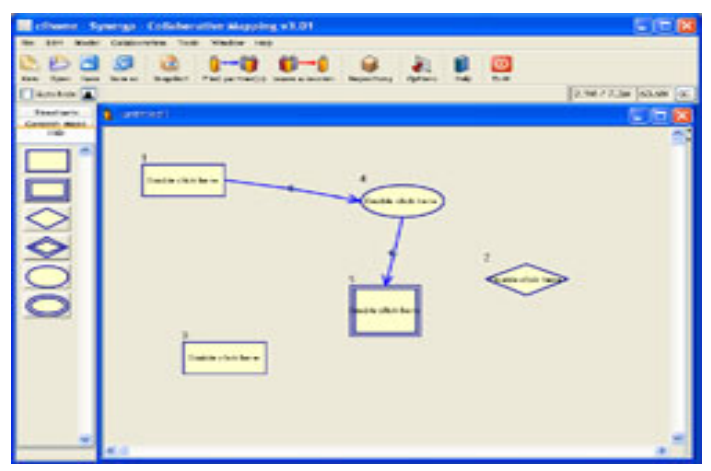

Figure 5. Synergo

In addition, a forum can be used for communication and discussion, allowing students to seek for social assistance from their peers, whenever they needed it .

\section{DISCUSSION AND CONCLUSION}

The present study attempted to explore the relationships between a selected set of self-regulated strategies and some personal characteristics and computers skills. To better understand the practical meaning of the observed relationships between these individual factors, we took advantage of these relationships, so as to create a well- designed e-learning environment that stresses the need for development of self-regulated strategies among learners.

Future research should focus on more qualitative aspects of this study, trying to find how personality traits influence learners to employ self-regulated learning, in the context of collaborated learning scenarios. Future research could also examine additional concepts from related models of self-regulated learning as to their relation to workplace environment. The findings of this study are tentative and need to be verified in further research. The main goal of this study was to bring to attention some connections between self-regulated learning and some other constructs, rather than providing definitive answers. Future research should carefully utilize the observed connections and help to assess educational scenarios, based on specific self-regulatory skills.

\section{ACKNOWLEDGMENTS}

This survey was conducted at the Department of Technology Education \& Digital Systems of the University of Piraeus. We would like to thank the postgraduate students who participated in the survey and enrolled voluntarily in the research project. Most of all, we would like to thank the Board of the Department for supporting this research.

\section{REFERENCES}

[1] P.R. Pintrich, and E. De Groot, "Motivational and self-regulated learning components of classroom academic performance", Journal of Educational Psychology, vol. 82(1), pp 33-40, 1990. (doi:10.1037/0022-0663.82.1.33)

[2] C. McNaught, Technology: The challenge of change, In R. King, D.Hill \& B. Hemmings (Eds.) University and diversity: Changing perspectives, policies and practices in Australia, New South Wales: KEON Publications, 2000.

[3] G. Hoban, C. Seraland, and B. Raine, "Can adult learners raise their self-efficacy for self-directed learning? A reflective challenge to some of our assumptions", in H. B. Long (Eds.) Self-directed learning and the information age, Motorola University Press, 2001.

[4] M. Boekaerts, and L. Corno, "Self-Regulation in the Classroom: A Perspective on Assessment and Intervention," Applied Psychology: An International Review, 54(2), 199-231, 2005. (doi:10.1111/j.1464-0597.2005.00205.x)

[5] M. Makri-Botsari, F. Paraskeva, E. Koumbias, A. Dendaki, and P. Panaikas, "Skills in computer use, self-efficacy and self-concept", In $1^{\text {st }}$ International Conference of Psychology and IT 2004: Human Perspectives in the Internet Society: Gender, Psychology \& Culture, Sept. 6-10, Spain, 2004.

[6] A. Collazos César, A. Guerrero Luis, A. Pino José, F. Ochoa Sergio and Stahl Gerry, "Designing Collaborative Learning Environments Using Digital Games", Journal of Universal Computer Science, vol. 13, no. 7, 1022-1032, 2007.

[7] S. Povatong, National education act of B. E. 2542, Bangkok: Office of the National Education Commission. (1999).

[8] B.J. Zimmerman, "Attaining self-regulation: a social-cognitive perspective", in M. Boekarts, P.R. Pintrich, and Zeidner, M. (eds), Handbook of Self-Regulation, San Diego, Academic Press, 2000. (doi:10.1016/B978-012109890-2/50031-7)

[9] C. Chen, "Self-regulated learning strategies and achievement in an introduction to information systems course," Information Technology, Learning and Performance Journal, vol. 20, No. 1, pp. 11-23, 2002.

[10] S. Sharma, G. Dick, W. Chin, L. Land, "Self-regulation and elearning" In Proceedings of the Fifteenth European Conference on Information Systems (Österle H, Schelp J, Winter R eds.), 383394, University of St. Gallen, St. Gallen pp.383 - 394, 2007. Available at: $\underline{\text { http://is2.1se.ac.uk/asp/aspecis/20070157.pdf }}$ 


\section{Designing Collaborative LeARning ENVIRONMENTs Using EdUCATIONAL SCENARIOS BASED ON SELF-REGULATION}

[11] R. Lynch, and M. Dembo, "The relationship between SelfRegulation and online learning in a blended learning context. International Review of Research in Open and Distance Learning, 2004, Available at: http://www.irrodl.org/content/v5.2/lynchdembo.html.

[12] D. Zhang, and J.F. Nunamaker, "Powering e-learning in the new Millennium: An overview of e-learning and enabling technology. Information Systems Frontiers, 5 (2), 207-2002, 2003. (doi:10.1023/A:1022609809036)

[13] M. Martinez, "High Attrition Rates in e-Learning: Challenges, Predictors, and Solutions", The eLearning Developer's Journal, July 14, 2003, 1-9.

[14] M. Bong and E. M. Skaalvik, "Academic self-concept and selfefficacy: How different are they really?", Educational Psychology Review, Vol. 15, No. 1, 2003. (doi:10.1023/A:1021302408382)

[15] R.W. Lent, S.D. Brown, and P.A. Gore, "Discriminant and predictive validity of academic self-concept, academic selfefficacy, and mathematics-specific self-efficacy. Journal of Counseling Psychology, 44, 3, 307-315, 1997. (doi:10.1037/00220167.44.3.307)

[16] A. Bandura,. Social foundations of thought and action. Englewood Cliffs, NJ: Prentice Hall, 1986.

[17] D. R. Compeau, and C. A. Higgins, "Social cognitive theory and individual reactions to computing technology: A longitudinal study". MIS Quarterly, 23(2), 145-159, 1999. (doi:10.2307/249749)

[18] A. Bandura, Self-Efficacy: The Exercise of Control, Freeman, New York, 1997.

[19] K.H. Smith, "Using the social cognitive model to explain vocational interest in information technology", Information Technology, Learning and Performance Journal, Vol. 20, No. 1, 2002.

[20] R. Karsten, and R. M. Roth, "The relationship of computer experience and computer self-efficacy to performance in introductory computer literacy courses", Journal of Research on Computing in Education, 31(3), 14-24, 1998

[21] D.R. Compeau, and C.A. Higgins, "Computer self-efficacy: Development of a measure and initial test", MIS Quarterly, 19(2), 189-211, 1995. (doi:10.2307/249688)

[22] M.E. Gist, C. Schwoerer, and B. Rosen, "Effects of alternative training methods on self-efficacy and performance in computer software training", Journal of Applied Psychology, 74(6), 884891, 1989. (doi:10.1037/0021-9010.74.6.884)

[23] B. J. Zimmerman, A. Bandura, and M. Martinez-Pons, "Selfmotivation for academic attainment: The role of self-efficacy beliefs and personal goal setting" , American Educational Research Journal, 29, 663-676, 1992.

[24] F. Pajares, "Current directions in self-efficacy research". In M. Maehr \& P. Pintrich (Eds.) Advances in Motivation and Achievement, CT: JAI Press vol. 10, pp. 1-49, 1997.

[25] C. A. Wolters, P. R. Pintrich, and S. A. Karabenick, "Assessing Academic Self-regulated Learning", Indicators of Positive Development Conference March 12-13, 2003, Available at: http://www.childtrends.org/Files/WoltersPintrichKarabenickPaper. pdf.

[26] D.H. Schunk, "Goal and self-evaluative influences during children's cognitive skill learning", American Educational Research Journal, 33, 359-382, 1996.

[27] I. Lee, Searching for new meanings of self-regulated learning in elearning environments, $2004 . \quad$ Available at: http://dasan.sejong.ac.kr/ inlee/set/articles/searching_040426.pdf.
[28] C.B. Hodges, "Self-Regulation in Web-based Courses: A Review and the Need for Research", Quarterly Review of Distance Education, 6 (4), 375-428, 2005.

[29] G. Salomon, Communication and education. San Francisco, CA: Jossey-Bass, 1983.

[30] M. Boekaerts, P.R Pintrich, and M. Zeidner, Handbook of selfregulation, San Diego, CA: Academic Press. 2000.

[31] M.I. Beas, and M. Salanova, "Self-efficacy beliefs, computer training and psychological well-being among information and communication technology workers", Computers in Human Behavior, Vol. 22, pp.1043-1058, 2006. Available at: http://www.elsevier.com/locate/comphumbeh. (doi:10.1016/j.chb.2004.03.027)

[32] P. R. Pintrich, D.A.F. Smith, T. Garcia, and W.J. McKeachie, "Reliability and predictive validity of the motivated strategies for learning questionnaire (MSLQ)", Educational and Psychological Measurement , vol. 53 , pp. 801 - 803, 1993. (doi:10.1177/0013164493053003024)

[33] C.A. Murphy, D. Coover, and S.V. Owen, "Development and validation of the Computer Self-Efficacy Scale", Educational and Psychological Measurement, 49, 893-899, 1989. (doi:10.1177/001316448904900412)

[34] J. Neemann, \& S. Harter, Manual for the Self-Perception Profile for College Students, Denver, CO: University of Denver Pres, 1986.

[35] I. Falconer, G. Conole, A. Littlejohn, and A. Jefferey "Learning Activity Reference Model - Pedagogy guide," LADIE project output. JISC. 2006.

[36] B. J. Zimmerman, "A social cognitive view of self-regulated academic learning", Journal of Educational Psychology, 81(3), p. 337, 1989. (doi:10.1037/0022-0663.81.3.329)

[37] B. J. Zimmerman, "Academic studying and the development of personal skill: a self-regulatory perspective", Educational $\begin{array}{llll}\text { Psychologist, } & 33(2 / 3), & \text { p.73-86, } & 1998 .\end{array}$ (doi:10.1207/s15326985ep3302\&3_3)

[38] N. Avouris, M .Margaritis, and V. Komis, "Modelling interaction during small-group synchronous problem solving activities: the Synergo approach," 2nd International Workshop on Designing Computational Models of Collaborative Learning Interaction, ITS 2004, 7th Conference on Intelligent Tutoring Systems, Maceio, Brazil, 2004.

[39] M. Margaritis, C. Fidas.and N. Avouris, "A framework to facilitate building of collaborative learning applications", Special Issue on Technology for Collaborative Learning, Advanced Technology for Learning (ATL) International Journal, vol 4, no 1 pp. 34-49, 2007.

\section{AUTHORS}

F. Paraskeva is with the Department of Technology Education and Digital Systems (TEDS), University of Piraeus, Greece, as a Lecturer. (e-mail: fparaske@unipi.gr).

S. Mysirlaki is MSC student in TEDS of University of Piraeus and a teacher in primary education. (e-mail: smyrsila@unipi.gr).

E. Choustoulakis is MSC student in TEDS of University of Piraeus (e-mail: manos_ted@unipi.gr).

Manuscript received 4 July 2008. Published as submitted by the authors. 